\title{
Stability of T-DNA integration in Phalaenopsis "Sogo Vivien" transgenic orchid carrying 35S::Gal4::AtRKD4::GR
}

\author{
Endang Semiarti ${ }^{1, *}$, Exsyupransia Mursyanti ${ }^{2}$, Ahmad Suyoko ${ }^{1}$, Faiza Senja Widya Perdana ${ }^{1}$, \\ Catharina Tri Widyastuti ${ }^{1}$, Aditya Nur Subchan ${ }^{1}$ \\ ${ }^{1}$ Faculty of Biology, Universitas Gadjah Mada, Jl. Teknika Selatan, Sekip Utara, Yogyakarta 55281, Indonesia. \\ ${ }^{2}$ Faculty of Technobiology, Universitas Atma Jaya, Jl. Babarsari, Yogyakarta, Indonesia \\ Author correspondency*: \\ endsemi@ugm.ac.id
}

\begin{abstract}
Orchid is an elegant ornamental plant and favoured by the society. Phalaenopsis "Sogo vivien" is a mini-sized orchid with an interesting white-striped purple petals. This study was aimed to analyze the stability of the integration of embryonic gene carrier T-DNA from Arabidobsis AtRKD4 into the P. "Sogo vivien" genome produced in 2016. The study was conducted in 3 stages: 1) Transgenic plant phenotype analysis (1 year old); 2) Examination of T-DNA integration in orchid genotypes using PCR. 3) Analysis of transgenic plant leaf explants' ability to produce somatic embryo in vitro. In vitro cultures were performed on the base medium of New Phalaenopsis (NP), plus various concentrations of TDZ $\left(0,1,2 \mathrm{mg} . \mathrm{L}^{-1}\right)$ and IBA $\left(0,1,2 \mathrm{mg} \cdot \mathrm{L}^{-1}\right)$ or without TDZ and IBA as controls. The transgenic Phalaenopsis "Sogo vivien" were transferred to pot mediums via ex vitro with two treatments: the first leaves were cut as explants for in vitro culture, and the plants were transferred to the mixture of fern medium with bark shavings. The integration of T-DNA in the genome was detected by DNA genome amplification from the second leaves using the AtRKD4 gene primers and the $P O H 1$ gene. The results showed that the highest number of somatic embryo (SE) propagules or protocorm like bodies (PLBs) amounted to 27 were derived from transgenic plant \# 2 cultured on NP $+2 \mathrm{mg} . \mathrm{L}^{-1} \mathrm{TDZ}+1 \mathrm{mg} . \mathrm{L}^{-1}$ IBA medium. The presence of AtRKD4 transgenes were detected with the amplification of $380 \mathrm{bp}$ of the RKD4 gene from the genome of transgenic plant \# 2 by using PCR. There were 2 out of 15 plants that positively carry the AtRKD4 gene and produce SE. Thus, the stability of the AtRKD4 carrier T-DNA integration in the genomes of transgenic plants was $13.3 \%$.
\end{abstract}

Keywords: Phalaenopsis "Sogo vivien"; AtRKD4; somatic embryo; stable transgenics

\section{INTRODUCTION}

Indonesia is home of tropical orchids, more than 5000 of 30,000 species of orchids in the world exist in Indonesia. Orchids are much favored by the society because of their beauty and attractive appearances. One of the popular ornamental orchids is Phalaenospsis "Sogo vivien" that has a beautiful, unique, and long lasting blooming period of about 3 months (McKinley, 2005). P. "Sogo vivien" has mini- to medium-sized flowers with purple as the main colour of its petals. One uniqueness of this orchid is the genetic mutation that causes the colour of its leaves' borders white, called as variegata. However, the percentage of mutation frequencies for the formation of this phenotype is only about $0.007 \%$ (Fig. 1, Mursyanti et al., 2016).

Orchid propagation by seed is naturally difficult because most of orchid seeds do not have endosperm, thus it requires symbiosis and have a low seed survival percentage. In vitro culture is the best solution for the cultivation of orchid plants. In vitro propagation can be performed using seed parts or other parts of plants such as leaves, roots and internodes of flower stems (Vendrame et al., 2007). In a previous study, $17 \mathrm{~T}-1$ plantlets from 2648 protocorms were produced through the formation of somatic embryos, which later developed into 413 T-2 transgenic plantlets (Mursyanti et al., 2015). However, the phenotypes resulting from the genetic transformation are still variable and unstable because of the possibility of genetic segregation from crossover results. To see the stability of transgenes integration in $P$. "Sogo vivien", a molecular analysis is required to see the stability of the gene. In this study, the object of our research is confirming the stability of $35 \mathrm{~S}$ $\because$ AtRKD4 integrationin the transgenic plant genome originated from T-2 generation and its ability to induce somatic embryogenesis in vitro through the overexpression of AtRKD4 gene in the transformant plants.

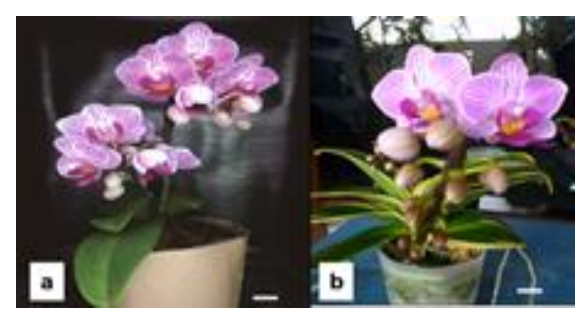

Figure 1. The morphology of Phalaenopsis 'Sogo Vivien'. (a) Normal plant with green leaves; (b) Mutated plant with white borders on the leaves. Bar: $1 \mathrm{~cm}$ (Mursyanti et al., 2016). 
Mursyanti et al. (2015) has successfully produced transgenic plantlets that has been transfered with $35 \mathrm{~S}:$ : AtRKD4 gene. Through the insertion of AtRKD4 gene, it was expected to increase germination rate due to the $R W P-R K$ motif causes the AtRKD4 gene to work in the very early stage of embryogenesis (Waki et al., 2011). Regarding to the potential of the transformed plants, it is necessary to do propagation efforts to maintain the plant's phenotypes. This research was conducted to acquire $P$. "Sogo Vivien" transgenic plants which carry $35 S: \because$ AtRKD4 containingT-DNA; to understand the growth of the transgenic $P$. "Sogo Vivien" and the nontransgenic plants, to obtain stable transgenic plants of Phalaenopsis "Sogo Vivien" that carry 35S :: AtRKD4 containingT-DNA for induction of somatic embryogenesis; and to determine the most effective medium for induction of somatic embryogenesis using the leaf explants from Phalaenopsis "Sogo Vivien" that carry the AtRKD4 gene. The transgenic orchid plant $P$. "Sogo Vivien" can be used for the development of somatic embryos using the whole plant to meet the market demand.

\section{MATERIALS AND METHODS}

\section{Plant materials and culture conditions}

The one year old transgenic plants $P$. "Sogo Vivien" carrying $35 S: \because$ Gal4 $\because$ AtRKD4 $\because$ GR that obtained from the previous research at the Laboratory of Biotechnology, Faculty of Biology UGM were used as a source of explants for in vitro induction of SEs (PLBs). Plantlets were overplanted into a hormone-free NP medium for refreshment. Cultures were maintained under continuous white light, at $25-28^{\circ}$ Celcius.
Isolation of genomic DNA genes and Detection of TDNA integration into the genomes of transgenic plants

Plant genomic DNA was isolated using a method as described by Semiarti et al. (2007), and the isolated DNA genome of transgenic plants were purified using the DNA Kit DNA MyTaqTM HS following procedure in the instruction manual described by BIOLINE (UK). Based on the structure ofT-DNA (Figure 2), detection of T-DNA integration was performed by amplifying AtRKD4 gene fragments with specific primers for AtRKD4: AtRKD4 F1 and AtRKD4 R1, that a mplified 380 bp DNA fragments. The primer sequences would be served upon request.

In vitro induction of somatic embryos from leaf explants of transgenic plants

The first leaves of the transgenic plants $P$. "Sogo Vivien" were cut into two parts in the middle, the distal and proximal parts of leaf were used as explants. The explants were introduced into NP medium with addition of various concentration of Thidiazuron (TDZ) growth regulator (0, 1, 2 mg.L-1) and Indole Butyric Acid (IBA) $(0,1,2$ mg.L-1). Cultures were maintained with continuous white light at $25-28^{\circ} \mathrm{C}$. The growth of explants were observed until the propagules were formed, which then developed into SE or called as protocorm-like body (PLB), the term of 'protocorm' is a special term for the development of spherical orchid embryos. The calculated SE and the stability of T-DNA integration in the orchid genome were indicated by the detection/amplification of the AtRKD4 gene from the genomic DNA of the transgenic plants, indicating stable plant genomes that carry $35 S \because:$ Gal4 $: \because$ AtRKD4 $\because: G R$ containing T-DNA (Figure 2).

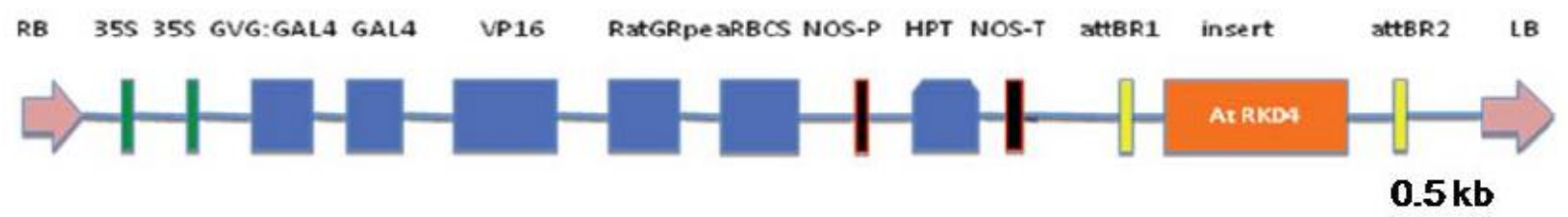

Figure 2. The structure of T-DNA carrying $35 S \because: G A L 4: \because$ AtRKD4 $\because: G R$ (Mursyanti et al, 2015).

\section{RESULTS AND DISCUSSION}

\section{Results}

Phenotypes of transgenic plants carrying $35 S::$ Gal4 $\because:$ AtRKD4 $:: G R$

In this study, 15 transgenic plants lines of $P$. "Sogo vivien" which carries $35 S: \because$ Gal4 $\because:$ AtRKD4 $\because:$ GR were obtained (Figure 4 and Table1). The phenotypes of the transgenic plants showed smaller size compared to the control of non-transgenic plants with normal plant size (Figure 3), especially in leaf length, leaf width, and plant height. 


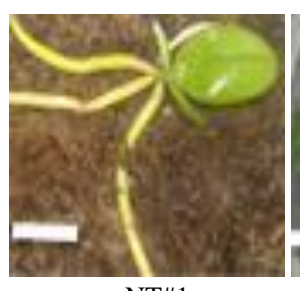

NT\#1

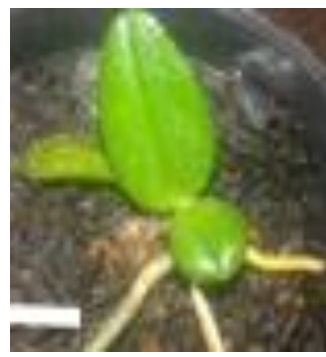

NT\#6

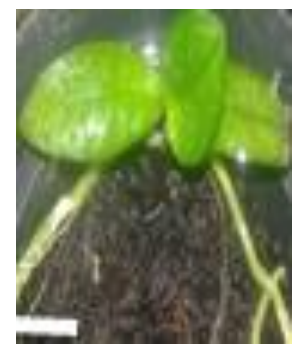

NT\#11

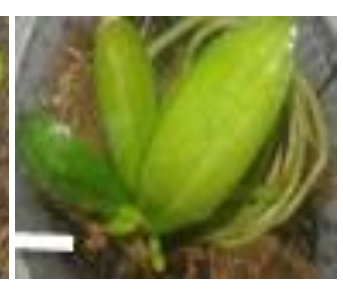

NT\#2

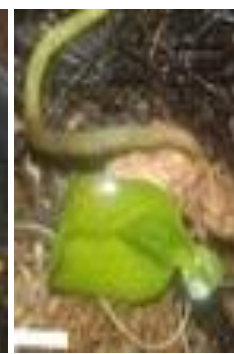

NT\#7

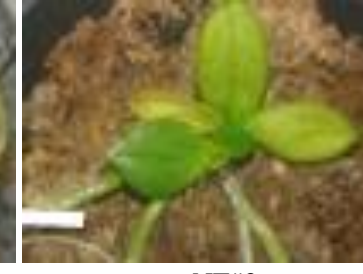

NT\#3

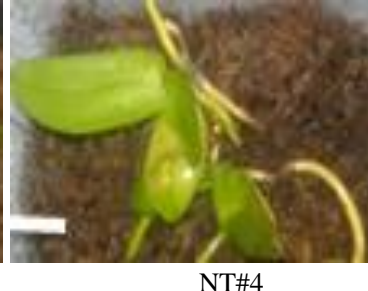

NT\#4

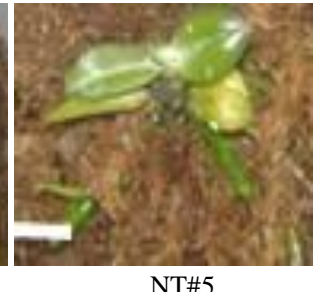

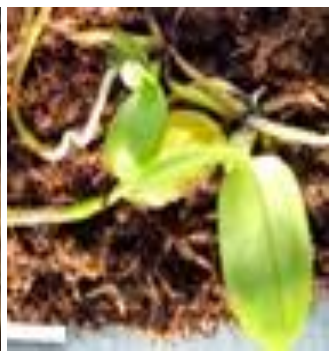

NT\#8

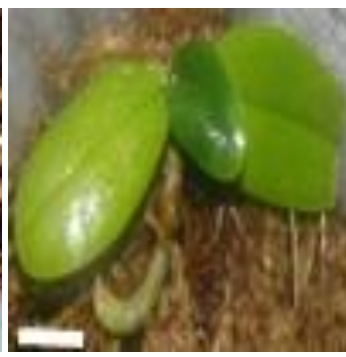

NT\#9

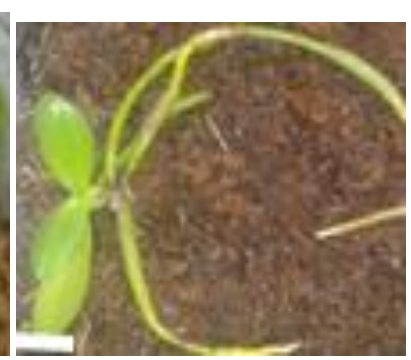

NT\#10

Figure 3. Phenotypes of non-transgenic $P$. "Sogo Vivien" plants, 8 weeks after transplanted into the pots. Bars: $1 \mathrm{~cm}$.
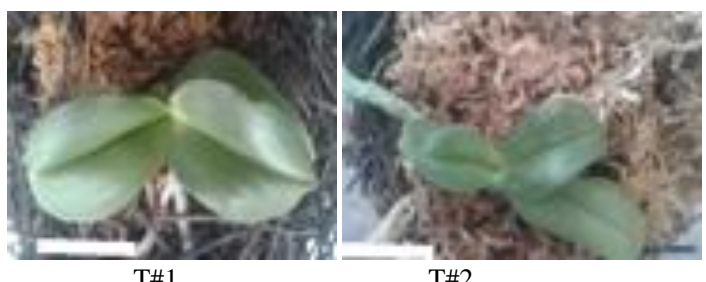
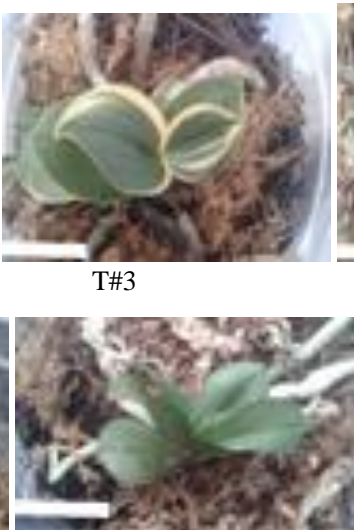

T\#8

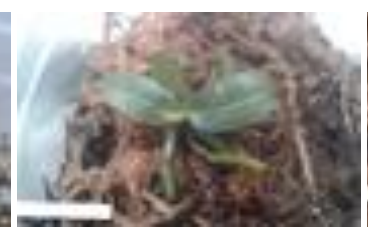

$\mathrm{T} \# 13$

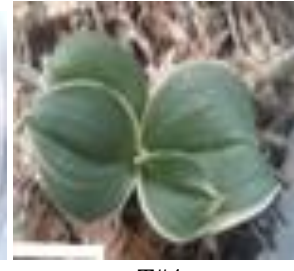

T\#4

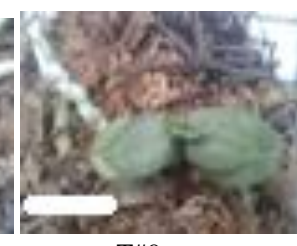

T\#9

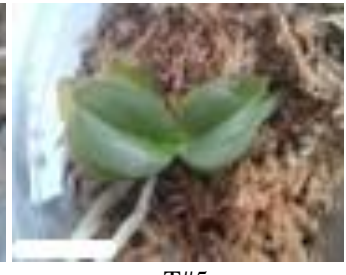

T\#5

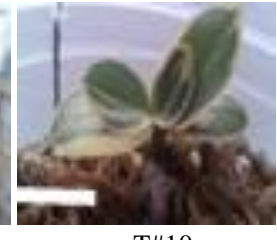

T\#10

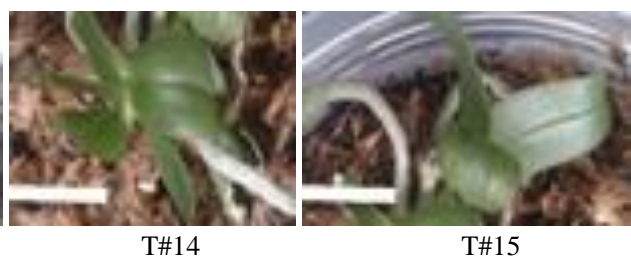

Figure 4. Phenotypes of transgenic $P$. "Sogo Vivien" plants that carry $35 S:: G a l 4: \because A t R K D 4: \because G R . \mathrm{T}=$ transgenic plant lines \# 1- \# 15; Bars: $1 \mathrm{~cm}$. 
Table 1. The vegetative growth of transgenic $P$. "Sogo Vivien" carrying $35 S: \because G a l 4: \because A t R K D 4: \because G R$ on 8 weeks after transplanted into pots.

\begin{tabular}{|c|c|c|c|c|c|}
\hline & \multicolumn{5}{|c|}{ Scale $(\mathrm{cm})$} \\
\hline & Plant height & First leaf length & First leaf width & The last leaf length & The last leaf width \\
\hline Non transformant & $2.0 \pm 0.5$ & $4.7 \pm 0.6$ & $2.3 \pm 0.6$ & $4.7 \pm 0.8$ & $2.8 \pm 0.4$ \\
\hline Transformant & $1.6 \pm 0.59$ & $2.4 \pm 0.72$ & $1.32 \pm 0.42$ & $2.2 \pm 0.32$ & $1.2 \pm 0.22$ \\
\hline
\end{tabular}

As shown in Table 1, transgenic plants produced higher number of leaves and roots compare to that of non-transgenic/normal plants. The detection of T-DNA integration into the orchid genome using PCR analysis showed that $380 \mathrm{bp}$ of AtRKD4 DNA fragments were detected from the genomic DNA of transgenic plant line \# 1 and line \# 2, thus it proved that the T-DNA is stably integrated in the genomes of orchid transgenic (Figure $6)$.
Table 2. Detection of AtRKD4 transgene in the genome of transgenic orchid.

\begin{tabular}{lccc}
\hline No. & $\begin{array}{c}\text { PCR Detection } \\
\text { of } \text { AtRKD4 }\end{array}$ & \multicolumn{2}{c}{ Somatic Embryos } \\
& POH1 & TDZ:IBA (2:1) \\
\hline NT\#1 & - & - & 0 \\
T\#1 & - & + & 0 \\
T\#2 & ++ & - & 27 \\
T\#3 & - & - & - \\
T\#4 & ++ & - & - \\
\hline Notes: IBA= Indol Butyric Acid (ppm), TDZ= Thiadizuron (ppm), \\
NT: Non Transgenic, T\#1-T\#4: Transgenic plant lines\#1- line \#4
\end{tabular}

Table 3. Percentage of living explants, somatic embryos and the colour change of in vitro transgenic T\#2 orchid $P$. "Sogo Vivien" carrying AtRKD4 gene in various media with the combination of TDZ and IBA, 4 weeks after plantation.

\begin{tabular}{|c|c|c|c|c|c|c|}
\hline \multirow[t]{2}{*}{$\begin{array}{l}\text { Treatment } \\
\text { media }\end{array}$} & \multirow[t]{2}{*}{$\begin{array}{c}\sum \text { explants } \\
\text { observed }\end{array}$} & \multirow[t]{2}{*}{$\begin{array}{l}\sum \text { and the percentage } \\
\text { of living explants }(\%)\end{array}$} & \multirow[t]{2}{*}{$\begin{array}{c}\sum \text { and the percentage of explants } \\
\text { forming somatic embryo candidates }(\%)\end{array}$} & \multicolumn{3}{|c|}{$\sum$ explants changing colours } \\
\hline & & & & Green & Yellow & Brown \\
\hline $\mathrm{NP}+\mathrm{T}_{0} \mathrm{I}_{0}$ & 9 & $5(55.6 \%)$ & $4(44.4 \%)$ & 6 & 1 & 2 \\
\hline $\mathrm{NP}+\mathrm{T}_{0} \mathrm{I}_{1}$ & 9 & $5(55.6 \%)$ & $1(11.1 \%)$ & 5 & 1 & 3 \\
\hline $\mathrm{NP}+\mathrm{T}_{0} \mathrm{I}_{2}$ & 9 & $8(88.9 \%)$ & $0(0 \%)$ & 8 & 1 & 0 \\
\hline $\mathrm{NP}+\mathrm{T}_{1} \mathrm{I}_{0}$ & 9 & $0(0 \%)$ & $0(0 \%)$ & 0 & 9 & 0 \\
\hline $\mathrm{NP}+\mathrm{T}_{1} \mathrm{I}_{1}$ & 9 & $1(11.1 \%)$ & $0(0 \%)$ & 1 & 3 & 5 \\
\hline $\mathrm{NP}+\mathrm{T}_{1} \mathrm{I}_{2}$ & 9 & $1(11.1 \%)$ & $0(0 \%)$ & 1 & 2 & 6 \\
\hline $\mathrm{NP}+\mathrm{T}_{2} \mathrm{I}_{0}$ & 9 & $4(44.4 \%)$ & $0(0 \%)$ & 4 & 1 & 4 \\
\hline $\mathrm{NP}+\mathrm{T}_{2} \mathrm{I}_{1}$ & 9 & $8(88.9 \%)$ & $6(66.7 \%)$ & 8 & 0 & 1 \\
\hline $\mathrm{NP}+\mathrm{T}_{2} \mathrm{I}_{2}$ & 9 & $5(55.6 \%)$ & $0(0 \%)$ & 5 & 0 & 4 \\
\hline
\end{tabular}

Table 4. Effect of growth regulator on the speed of somatic embryogenesis induction 4 weeks after explant plantation.

\begin{tabular}{cccccccccc}
\hline \multirow{2}{*}{ Plants } & \multicolumn{7}{c}{ Time of somatic embryogenesis induction (day) } \\
\cline { 2 - 9 } & $\mathrm{NP}+\mathrm{T}_{0} \mathrm{I}_{0}$ & $\mathrm{NP}+\mathrm{T}_{0} \mathrm{I}_{1}$ & $\mathrm{NP}+\mathrm{T}_{0} \mathrm{I}_{2}$ & $\mathrm{NP}+\mathrm{T}_{1} \mathrm{I}_{0}$ & $\mathrm{NP}+\mathrm{T}_{1} \mathrm{I}_{1}$ & $\mathrm{NP}+\mathrm{T}_{1} \mathrm{I}_{2}$ & $\mathrm{NP}+\mathrm{T}_{2} \mathrm{I}_{0}$ & $\mathrm{NP}+\mathrm{T}_{2} \mathrm{I}_{1}$ & $\mathrm{NP}+\mathrm{T}_{2} \mathrm{I}_{1}$ \\
\hline & 7 & 21 & 0 & 0 & 0 & 0 & 0 & 14 & 0 \\
$\mathrm{~T} \# 1$ & 7 & 0 & 0 & 0 & 0 & 0 & 0 & 3.5 & 0 \\
$\mathrm{~T} \# 2$ & 0 & 0 & 0 & 0 & 0 & 0 & 0 & 0 & 0 \\
$\mathrm{NT} 1$ & 0 & 0 & 0
\end{tabular}

Notes: $\mathrm{NP}=$ New Phalaenopsis Medium, T= Thidiazuron, I = Indol Butyric Acid NT: Non Transfromant, T\#1,T\#2: Transfromants 
Table 5. Propagule formation on the leaf explants from Non Transgenic and Transgenic $P$. "Sogo Vivien", 4 weeks after explant plantation on media containing TDZ and IBA.

\begin{tabular}{|c|c|c|c|c|c|c|c|}
\hline \multirow{3}{*}{ IBA } & \multirow{3}{*}{ TDZ } & \multicolumn{6}{|c|}{ Average number of propagule formation on explants } \\
\hline & & \multicolumn{2}{|c|}{ O ppm } & \multicolumn{2}{|c|}{$1 \mathrm{ppm}$} & \multicolumn{2}{|c|}{$2 \mathrm{ppm}$} \\
\hline & & Numbers & Morphology & Numbers & Morphology & Numbers & Morphology \\
\hline \multirow[t]{3}{*}{$0 \mathrm{ppm}$} & NT1 & 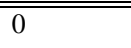 & & 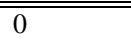 & & 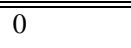 & 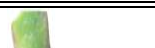 \\
\hline & $\mathrm{T} 1$ & 20.5 & & 0 & & 0 & \\
\hline & $\mathrm{T} 2$ & 2 & & 0 & & 0 & \\
\hline \multirow[t]{3}{*}{$1 \mathrm{pppm}$} & NT1 & 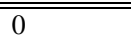 & & 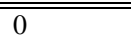 & & 3.4 & \\
\hline & $\mathrm{T} 1$ & 3 & & 0 & & 11 & \\
\hline & $\mathrm{T} 2$ & 0 & & 0 & & 27 & \\
\hline \multirow[t]{3}{*}{$2 \mathrm{ppm}$} & NT1 & 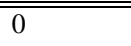 & & 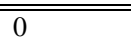 & & 0 & \\
\hline & $\mathrm{T} 1$ & 0 & & 0 & & 0 & \\
\hline & $\mathrm{T} 2$ & 0 & $y$ & 0 & & 0 & \\
\hline
\end{tabular}

Notes: IBA= Indole Butyric Acid (ppm), TDZ= Thidiazuron (ppm), NT: Non Transfromant, T1, T2: Transformant, Bars= $5 \mathrm{~mm}$. 


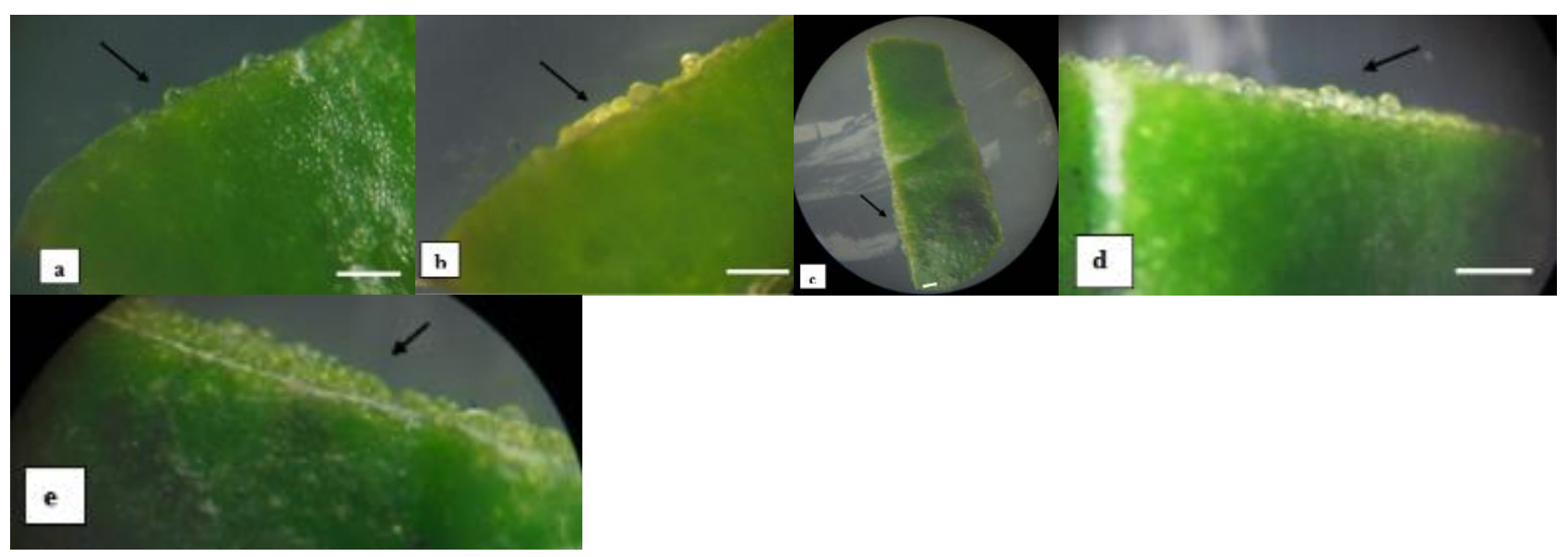

Figure 5. The process of somatic embryogenesis in the surface of leaf explants from transgenic orchid $P$. "Sogo vivien" carrying T-DNA $35 S::$ Gal4 $::$ AtRKD4 ::GR. (a) The formation of somatic pre-embryo/ PLB (arrow) on the part of the cuts 1 week after culturing on NP 0. (b) Formation of somatic pre-embryo (arrow) 4 weeks after culturing on NP 0. (c, d) Formation of somatic pre-embryo (arrow) 1 week after culturing on TDZ 2 ppm and IBA 1 ppm. (e) Formation of somatic pre-embryo (arrow) 4 weeks after culturing on TDZ medium 2 ppm and IBA 1 ppm, the colour turned into yellowish green. (Bars: $1 \mathrm{~mm}$ )

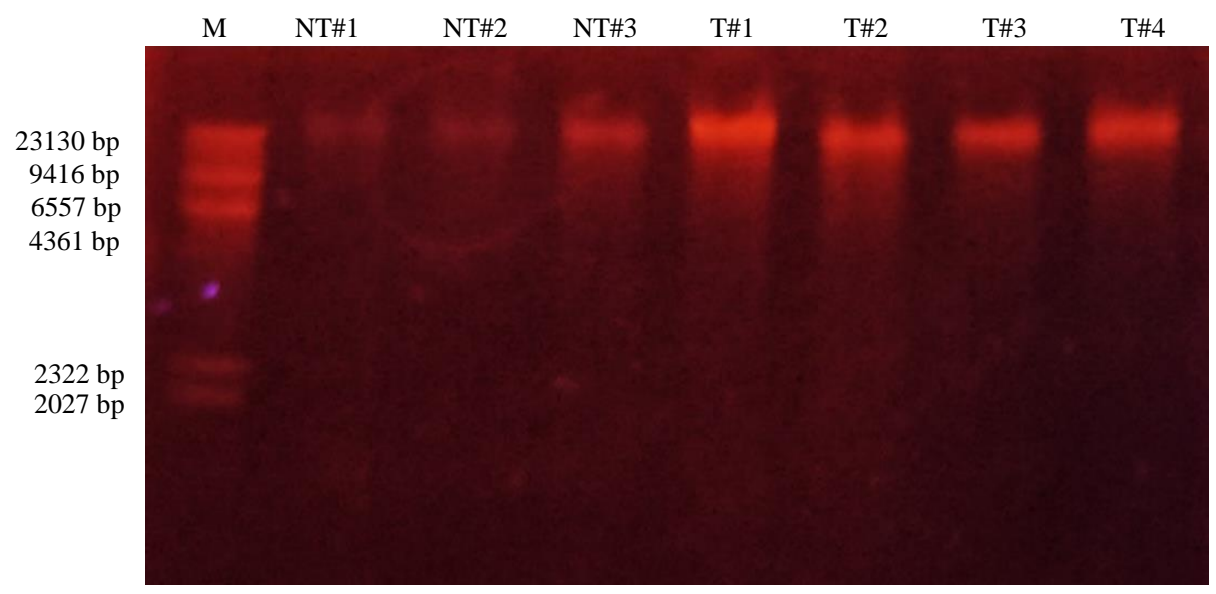

Figure 6. Electrophoregraph of genomic DNA (whole genome DNA) from the leaf of Phalaenopsis "Sogo Vivien". Non transformants(NT\#1, NT\#2, NT\#3) and transformant with T-DNA containing 35S::AtRKD4 (T\#1, T\#2, T\#3, T\#4) and $\lambda$ DNA/HindIII as DNA markers (M). .

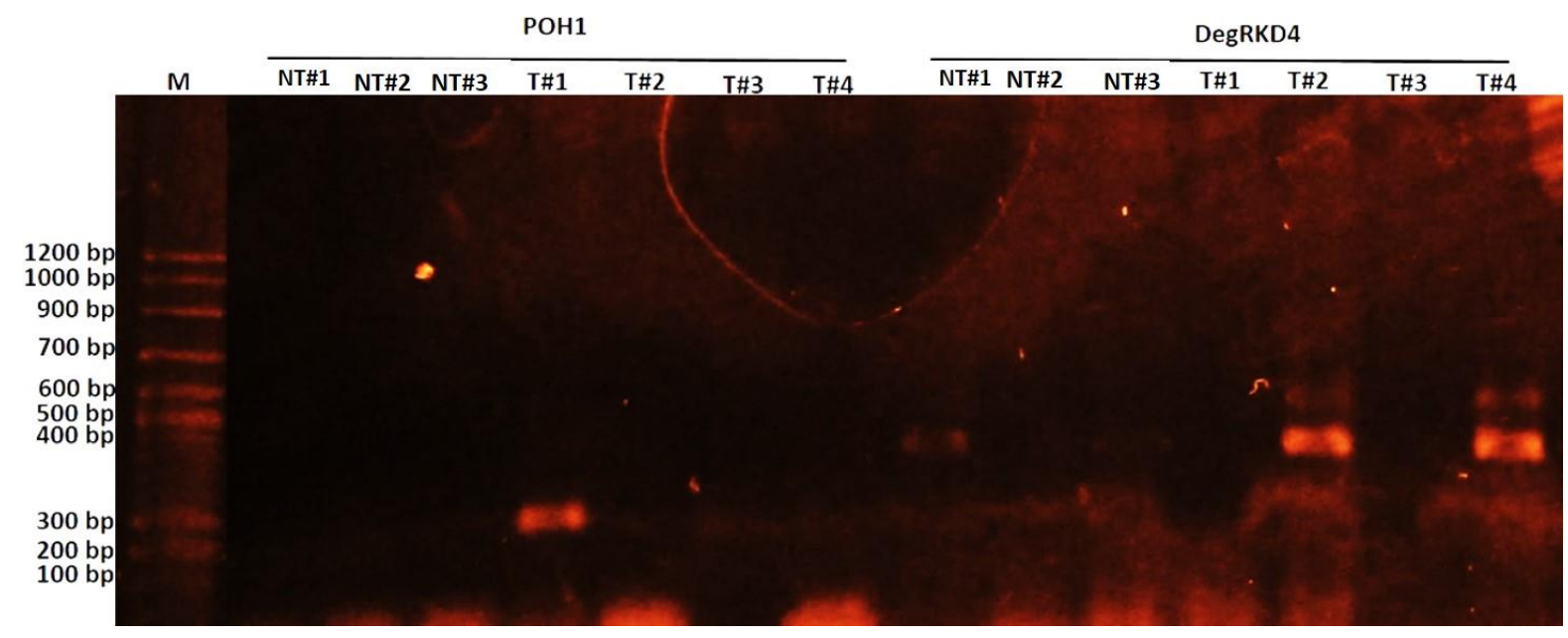

Figure 7. Electrophoregraph of amplified DNA by using PCR of genome DNA of $P$. "Sogo Vivien", both non-transformantand transformant carrying 35S::Gal4::AtRKD4::GR. The amplified DNA from non transformant plants (NT\#1, NT\#2, NT\#3) and trasnformant plants (T\#1, T\#2, T\#3, T\#4); Marker (M): 100 bp DNA ladder; Amplification of genome DNA using POH1 primer produced 300 bp sized band; DegRKD4 primer produced 380 bp sized band of DNA fragments. 


\section{Discussion}

The characteristics of vegetative growth in plant that are inserted by foreign genes (transgenic) and normal/nontransgenic plants may be the same or different depending on the expression level of the inserted gene. In most transgenic plants, the vegetative growth character is similar to that of normal plants. More than 100 apple cultivars of the Royal Gala carrying the uidA, $a l s$, and nptIII genes showed no difference at the morphological level, growth type, or response to environmental factors compared to non-transgenic plants (Bajaj, 2012: 242). In transgenic soybean plants carrying the ATPG7 gene, plant height is the same or more than non-transgenic plants (Kim et al., 2017: 237-242). However, this depends on the character of the genes inserted. For example, the broccoli plant (Brassica oleracea subsp. italica) that carries the heat-tolerant gene, AtHSP101 is slightly shorter than nontransgenic plants as the effect of position (Ravanfar et al., 2013: 14). The gene insertion site has an effect on gene expression when its location on the chromosome changes, and can cause silencing genes as well as DNA regulation.

The AtRKD4 gene is a gene that regulates gamet cell differentiation processes (Koi et al., 2016: 1775-1781) and can induce somatic embryogenesis in $P$. "Sogo Vivien" (Mursyanti et al., 2015: 26-37). This study was aimed to study the vegetative growth character of $P$. "Sogo vivien" that carries AtRKD4 gene compared to normal orchid plants. In general, there was no difference in the number of roots. Plant height differed from first week to seventh week but itswere no different at the eight week. This indicated that the growth of transgenic plant stems and normal plants become stable from the eighth week. The length of the basal leaf did not differ in the first week and the second week but were different until the eighth week. The same phenomenon happened on the basal leaf width. It suggests that there is a slightly difference of growth in basal leaves between transgenic and normal plants. The length of terminal leaf did not differ from the first week to the third week, but it began to be differed after the eighth week. The width of the terminal leaf did not differ in the first and second weeks and began to be differed from the third week to the eighth week. The growth difference between the terminal leaf of transgenic and normal plantsstarted from the third week.

Vegetative growth of transformantplants was slower than that of non-transformant plants that proved by ANOVA test for some growth parameters including plant height, basal leaf length and width, and terminal leaf length and width. Based on the ANOVA test, differences in the length and width of the first leaf and the length and width of the last leaf were detected.

The observation results on the number and percentage of live explants (Table 2) showed that, from the whole treatments, only the TDZ:IBA (1:0) media was not fit for survival, whereby all of the leaves had chlorosis. The different life-force responses of the explants may be due to the adaptability of the nonuniform explants and the physiological conditions of the explant source. During four weeks of planting, the explants changed colour to yellowish brown. Table 2 showed yellowish discoloration in all treatment mediums except TDZ: IBA (2: 1) and TDZ: IBA (2: 2), whereas for brown colour change occured in all treatment mediums except TDZ: IBA 0: 2) and TDZ: IBA (1: 0). Change of explants colour into yellow was caused by the occurrence of chlorosis. The phenomenon of chlorosis is resulted from the decreasing chlorophyll content in the explant. The decrease of chlorophyll content on media may be caused by the relativily low explants' ability to utilize iron micronutients. In a previous study, during in vitro culture of leaf explants, the chlorophyll content value was linear with iron concentration in culture medium (Sivanesan et al., 2008: 4482-4490). Some explants in some media changed its colour into brown. This indicated the occurence of browning symptoms of leaf explants. The process of browning might due to the oxidation of polyphenol compounds and the formation of quinon compounds. Both of these compounds are inhibited the growth of leaf tissue explants (Sukumar et al., 2008: 361). The emergence of the oxidation process is activated by oxidase enzyme after injury, the enzyme may leave the cell and possibly create bonds between hydrogen and proteins, increasing the activity of phenylalanine ammonia lyase, an enzyme that promotes the production of phenylpropanoid, resulting in the brownish color of the leaves (Hutami, 2008: 83- 88).

Of the total media with variation of hormones/growth regulators, there were 3 media treatments that successfully performed somatic embryogenesis induction (Table 2.). In induction media, 4 explants (NP 0), 1 explant (TDZ: IBA; 0: 1) and 6 explants (TDZ: IBA; 2: 1) were able to form candidates of somatic embryo. Compared with hormon-free media $(44.4 \%)$, media with a combination of TDZ: IBA $(2: 1)$ resulted in a larger percentage $(66.7 \%)$. These results support the results of previous studies, which suggested that the combination of exogenous auxin and cytokinin hormones can effectively induce direct somatic embryogenesis on Phalaenopsis orchid leaf explants (Feng and Chen, 2014: 4). The velocity induction of somatic embryogenesis processes varies (Tables 3 and 4.). Transgenic explants were successfully induced whereas non-transgenic explants did not undergo somatic embryogenesis formation. Transgenic plant T\#2 took 7 days in NP 0medium, and 3.5 days in TDZ: IBA (2:1) containing medium to form somatic embryos. Meanwhile, T\#1 plant took 7 days in NP 0medium, 21 days in TDZ: IBA (0: 1$)$ containing medium and 14 days in TDZ; IBA (2: 1) containing medium. The shortest time for SE induction occured on the transgenic planlet leaf explant in medium with TDZ: IBA (2: 1), which required a mean time of 3.5 days, twice faster than the 
SE induction in the control medium. The induction velocity was relatively faster compared to previous studies (Kasi and Semiarti, 2016: 31-40) using a wildtype $P$. "Sogo Vivien" which took 8 weeks after inoculation to form somatic embryos.

Table 5 showed that the results of somatic embryogenesis induction can be known directly through the observation of average propagule appearance on leaf explants, at 4 weeks after planting. The propagules produced from this induction process will develop into protocorm-like bodies (PLB), an orchid embryo derived from somatic cells, forming a swollen tuber, which then potentially form in vitro shoots (Kumar et al., 2008: 718). The propagules appeared in transgenic leaf explants $\mathrm{T} \# 1$ and $\mathrm{T} \# 2$, but not observed in nontransformantleaf explants. T\#1 transgenic leaf explants produced a mean of 20.5 propagules in NP 0 medium, 3 pieces in TDZ : IBA $(0: 1)$ medium, whereas the explants of $\mathrm{T} \# 2$ transgenic leaves produced 2 propagules in NP 0 medium and 27 propagules in TDZ: IBA (2: 1) medium. The results of this study showed that the transgenic leaf that carries AtRKD4 with a $35 \mathrm{~S}$ promoter was able to undergo somatic embryogenesis process directly on the medium without hormon and produce more embryos on TDZ: IBA (2:1) medium. The TDZ growth regulator requirement is relatively lower, which is $\leq 2 \mathrm{ppm}$, compared to a previous study (Kasi and Semiarti, 2016: 31-40) where wildtype $P$. "Sogo Vivien" required TDZ concentration of $10 \mathrm{ppm}$ for induction of somatic embryogenesis from leaves in vitro.

The results of in vitro inoculation of leaf explants of transgenic plants showed faster in induction speed of somatic embryogenesis (Table 4), with lower TDZ concentration requirement (Table 3, Table 4) and higher capability to form propagules in NP hormon-free medium Table 3, Figure 5). This is in line with our previous research which showed that high activity of AtRKD gene can induce somatic embryogenesis process on leaf explants (Mursyanti et al., 2016: 45-53). Based on all the results obtained, it was shown that the media with a combination of TDZ: IBA produced the highest number of propagules. These results suggest that the presence of exogenous hormones may support somatic embryogenesis induction in orchid.

Molecular analysis showed that the isolated DNA fragments from both non-transformant and transformant plants (Figure 6) indicated good quality of genomic DNA with no smear appearance in the electrophoresis gel. The genomic DNA amplification results with AtRKD4 specific primers and DegRKD4 degenerate primers indicated that the AtRKD4 transgene has been integrated into genomes of $P$. "Sogo Vivien" plant and the stably integrated in the orchid plant genome. Figure 7 showed that a $300 \mathrm{bp}$ DNA fragment was amplified from T\#1 genome using specific primers of $\mathrm{POH} 1$ gene and $380 \mathrm{bp}$ DNA fragment were amplified from T\#2 and $\mathrm{T} \# 4$ genomes using primers of AtRKD4 gene. Its indicates that the AtRKD4 transgene has only stably integrated in transgenic plant $\mathrm{T} \# 2$ and $\mathrm{T} \# 4$, Finally, we got the two stable transgenic lines $\mathrm{T} \# 2$ and $\mathrm{T} \# 4$, which are being acclimatize in the greenhouse and maintain for the next generation.

\section{CONCLUSION}

Integration of the T-DNA carrying $35 S: \because$ Gal4::AtRKD4::GR in the genome of transgenic plant Phalaenopsis "Sogo vivien" can be detected in 2 of 15 strains, thus it means the stability of T-DNA integration is $13.3 \%$. The morphology of transgenic plants did not change significantly in root quantities compared with non-transformant plants, but experienced significant differences in plant height, length, basal and terminal leaf width and length compared with nontransformant plants. The development of somatic preembryogenesis occurred after 4 weeks of culture characterized by the appearance of propagules on the surface of plant leaf explants.

\section{ACKNOWLEDGEMENTS}

This research was funded by a research grant Hibah Penelitian Biodiversitas Tropika Dosen Untuk Pengembangan Materi Pembelajaran BPPTNBh from the Faculty of Biology, Universitas Gadjah Mada on 2017 with contract number: UGM/BI/1734/UM/05/01.

\section{REFERENCES}

Bajaj, Y. P. S. 2012. Biotechnology in Agriculture and Forestry 47: Transgenic Crops II. Springer. New Delhi. p. 242.

Feng J and Cheng J.2014. 'A Novel In Vitro Protocol for Inducing Direct Somatic Embryogenesis in Phalaenopsis aphrodite without Taking Explants'. The Scientific World Journal. vol. 2014, Article ID 263642, 7 pages, 2014. doi: $10.1155 / 2014 / 263642$.

Hutami, S.2008. 'Masalah pencoklatan pada kultur jaringan.Jurnal Agrobiogen. 4(2).83-88

Kasi, P. D. dan Semiarti E.2008.'Pengaruh thiadizuron dan naphtalene acetic acid untuk induksi embriogenesis somatik dari daun anggrek Phalaenopsis "Sogo Vivien". Jurnal Dinamika. 7(1):31-40.

Kim, H. J. Cho, H. S. Pak, J. H. Kim, K. J. Lee, D. H. and Chung, Y. S. 2017. Overexpression of a Chromatin ArchitectureControlling ATPG7 has Positive Effect on Yield Components in Transgenic Soybean. Plant Breed. Biotech. 5(3):237-242.

Kumar A, Neumann K and Sopory S K. 2008. Recent Advances in Plant Biotechnology and its Applications.I.K. International. New Delhi. p. 718.

Koi, S. Hisanaga, T. Sato, K. Shimamura, M. Yamato, K. T. Ishizaki, K. Kohchi, Y. and Nakajima, K. 2016. An evolutionary conserved plant RKD factor controls germ cell differentiation. Curr. Biol. 26(13): 1775-1781. 
McKinley, M. 2005. Complete Guide To Orchids: Ortho Books. American Orchid Society. USA. p.137.

Mursyanti, E., Aziz-Purwantoro, S. Moeljopawiro and E. Semiarti. 2015. Induction of Somatic Embryogenesis through Overexpression of AtRKD4 Genes in Phalaenopsis 'Sogo Vivien'. Indonesian Journal of Biotechnology. 20(1): 26-37.

Mursyanti, E., Aziz-Purwantoro, S. Moeljopawiro and E. Semiarti. 2016. Micropropagation of Mini Orchid Hybrid Phalaenopsis 'Sogo Vivien', Journal of Tropical Biodiversity and Biotechnology. 1(1): 45-53.

Ravanfar, S. A. Aziz, M. A. Shabanimofrad, M. and Samarfard, S. 2013. Greenhouse evaluation on the performance of heat tolerant transgenic broccoli and genetic diversity analysis using inter simple sequence repeat (ISSR) markers. Electronic Journal of Biotechnology. 16(5): 1-4.

Semiarti E., Indrianto A., Purwantoro A., Isminingsih S., Suseno, N., Ishikawa T., Yoshioka Y., Machida Y.,and Machida C. 2007. Agrobacterium-mediated transformation of the wild orchid species Phlaenopsis amabilis. Plant Biotechnology 24: 265-272.

Sivanesan I, Hwang SJ and Jeong B R.2008. 'Influence of plant growth regulators on axillary shoot multiplication and iron source on growth of Scrophularia takesimensis Nakai- a rare enemic medicinal plant'.African Journal of Biotechnology. 7(24):4484-4490.

Sukumar E, Essa M M and Manickavasagan A. 2012. Dates. Production, Processing, Food and Medicinal Values. CRC Press. New York. P. 361.

Vendrame, W. A. Maguire, I. and Carvalho, V. S. 2007. In vitro Propagation and Plantlet Regeneration from Doritaenopsis Purple Gem 'Ching Hua' Flower Explants. Hort. Science. 42:1256-1258.

Waki, T., T. Hiki, R. Watanabe, T. Hashimoto \& K. Nakajima. 2011. The Arabidopsis RWP-RK protein

RKD4 triggers gene expression and pattern formation in early embryogenesis. Current Biology. 21(15): 1277-1281. 
THIS PAGE INTENTIONALLY LEFT BLANK 